\title{
江戸幕府の彫物大工棟梁和泉・高松両家について STUDY ON TWO FAMILIES NAMED IZUMI AND TAKAMATSU AS THE MASTER-CARVER WHO BELONGED TO SAKUZIKATA DEPARTMENTT OF THE TOKUGAWA SYOGUNATE
}

\author{
伊東龍一* \\ Ryuichi ITO
}

The Tokugawa Syogunate constructed buildings richly decorated with carves, and temples and shrines in the Kanto district also often had carves. In many cases, the carvers engaged in constructing the buildings of the Tokugawa Syogunate. This study deals with the carvers who belonged to the Tokugawa Syogunate. The major clarified factors are written as following.

There were two families named Izumi and Takamatsu in the position as master-carver.

The Izumis was from Senshu in the Kansai district and the Takamatsus was from the Kanto district.

Date of the Izumis activities is from the $3 \mathrm{rd}$ years of the Genroku (1690) to the end of the Edo era. Date of the Takamatsus activities is from the 5th years of Genroku (1692) to the 3rd years of Meiwa (1766).

The master-carver was on a level with the carpenter named 'daiku-toryo'. But. Izumi yosihisa, Izumi yosiyasu and Izumi yosisuke were raised to the master-carpenter named 'dai-toryo' in the end of the Edo era.

Keywords : carver, carpenter, Edo era

\section{1. 緒 言}

東照宮をはじめとする日光山内の社寺は郕物（㰹刻装 飾)を多用しているが,その造営や修理は江戸幕府によっ て行われた。その作事において彫物を担当した郕物大工 棟梁の名は, 元禄元年 (1690).の岸上加右衛門・同太郎 兵衛が初見である。この岸上家は，その後の和泉家につ ながることが認められ，以後，和泉家は幕末まで，高松 家は元禄 5 年 (1692) 以降明和 3 年 (1766)まで，その 地位にあっだ。

本稿は, 由緒書や過去帳・造営関係史料等を用いて, 幕府の彫物大工棟梁である和泉・高松両家について出身 地や活動期間, 彫物大工棟梁の所属 - 地位について検討 する。

和泉・高松両家の内, 和泉家については，すでに坂井 犀水『日本木雕史」(夕仏出版社 昭和 4 年) や大 熊喜邦「豊公聚楽第の大広間」(『建築史】2ノ1 昭和 15 年 1 月）が由緒書を用いて簡単な紹介をしており, 筆者は，前稿で和泉家由緒書の信頼性を検討し，系譜を 明らかにしている2〉。そこで，和泉家については，前稿 の結果を踏まえて, 彫物大工としての活動を中心に考察
を進めている。

一方，高松家については，これまで論考されたものが なく, 䧓物大工としての活動をその系譜をも含めて考察 している。

\section{2. 和泉家について}

\section{(1) 出身地}

出身地については泉州和泉郡和泉であることは由緒書 の記述からすでに指摘されている3!。由緒書は, 和泉家 の先祖岸上五良右衛門義忠が泉州和泉郡和泉に住み, 義 忠の子の義信は同所の産まれで，小右衛門義繁の代の慶 長 4 年（1599）に江戸へ出たと記している。また，義信 の菩提寺を貝塚の願泉寺としている4)。しかし、これら の記事は先に検討した由緒書の必ずしも信頼できるとは 限らない範囲にあり，検討を要する。

まず，岩木山神社本殿（青森県）正面軒唐破風内連獅 子彫刻の裏面墨書「貞享四乙卯歳卯月中旬：生国泉州貝 塚 岸上太郎兵衛作 武州江戸京橋辺住」5) から,この 彫物大工岸上太郎兵衛は泉州貝塚生まれで江戸京橋に住 んでいたことがわかる。この太郎兵衛は, 貞享頃活躍し 
ていたことから考えて, 系譜上の太郎兵衛行利（享保 9 年没 1724）に当たると考えられる。

また, 貝塚の願泉寺の住持了観が延享 3 年 (1746) に 記した『了観師記 万記録』によると, 寛文 3 年 (1663) の御堂再興に当り, 貝塚の和泉守が江戸から呼び戻され て棟梁を勤め, 䧓物を和泉守と共に豊後守・但馬守の三 人の兄弟が担当していだ)。この兄弟は, 同寺の住持了 真が文化 14 年 (1817) に記した棟札では, 和泉の岸上 万兵衛の子であるとしている7”。これより, 寛文頃, 貝 塚に岸上姓の彫物大工の兄弟が存在し, 影泉寺の彫物を 担当したことになる。由緒書には和泉家が江戸へ出た後 も泉州に類縁があったことが記されており ${ }^{8)}$, 万兵衛や 豊後守・但馬守は泉州に残った岸上家の一族であったと 考えられる。

願泉寺所蔵『貝侬大工之由緒, 大覚寺宮令旨之写, 棟 梁系図】9 の「貝塚彫物師」と題された系図には, 初名 を太郎兵衛といった和泉加右衛門近直が記されてお $\eta^{10)} ， 3$ 代加右衛門義乗あるいは太郎兵衛行利に当たる 可能性がある。

貞享 4 年 (1687) に新長谷寺本堂 (岐阜県) の丸彫の 手挟を堺の岸上六兵衛真勝が'1), 正徳 2 年 (1712) に難 波別院本堂 (大阪府) の彫物を大阪の岸上五兵衛尉が担 当したこと ${ }^{12)}$ が棟札などから知られ，堺や大阪で岸上姓 の彫物大工が活躍したことがわかる。

以上のような諸状況を考え合わせると, 和泉出身の彫 物大工である岸上家が存在し, 江戸へ出て出身地名の和 泉を称したことは認めてもよいと考えられる。

\section{（2）歷代当主と活動}

和泉家関係で彫物大工の初見は, 先にみた貞享 4 年 （1687）の岩木山神社本殿の岸上太郎兵衛である。また, 幕府能物大工棟梁の初見である元禄 3 年 (1690) の日光 東照宮修理の岸上加右衛門・同太郎兵衛を姓名や年代か らみて和泉家の関係者である可能性が高い。また，由緒 書には, 甚五郎義信（永禄 12 年没 1569）の代から彫 物大工として活躍していたことが記されている年が，こ の記録は由緒書の 5 代九右衛門重義条より古い作事関係 記事に属し，この部分は史料として直ちに信頼すること はできない。しかし，7 代忠兵衛貞福以後は他の作事記 録亡対応できる ${ }^{14}$ ので，史料で確認できる先の太郎兵衛 行利と, これに続く 7 代忠兵衛貞福（安永 2 年没 1773) $\cdot 8$ 代九右衛門義壽（天保 14 年没 1843）・9 代九 兵衛良安（弘化 2 年没 $1845 ） \cdot 10$ 代九兵衛義藝（明治 15 年没 1882) と幕末の数代は幕府の彫物大工棟梁と して活動していたと考えられる。また，彫物大工として 活動を始めた時期については, 史料の信頼性の問題から 直ちに由緒書のとおり義信の代まで溯ることはできない が，系譜における初代で江戸時代初期の五郎助吉政（寛 永 11 年没 1634）の代からである可能性が強い。
また, 由緒書によれば, 8 代九右衛門義壽は, 彫物大 工棟梁と共に，文化 4 年（1807）7月 5 日に大工棟梁 ${ }^{15)}$ を, ついで天保 2 年 (1831) 12 月 16 日に大棟梁並 ${ }^{16)}$, 天保 5 年 8 月 10 日の大棟梁を兼任する ${ }^{17) 。 ま た, ~} 9$ 代 九兵衛良安は, 天保 5 年 11 月 2 日に大棟梁胃習 ${ }^{18)}$, 天 保 12 年 11 月 5 日にこれを免ぜられ, 元の通り彫物御用 だけを勤めるようになるが19)，天保 14 年 1 月 20 日には 大工頭支配大工棟梁並になっている 20 。1 10 代九兵衛儀 藝は天保 15 年 10 月 18 日に彫物方見習 ${ }^{21)}$, 嘉永 5 年 （1852）12月 1 日に彫物方22)，万延元年（1860）11月 5 日に大棟梁並になっている23)。これらは, いずれも由 緒書の信頼できる範囲にある記録で，すでに 8 代義壽が 大棟梁並及び大棟梁, 10 代義藝が大棟梁並の地位にあっ たことは他の史料からも確認される24)。

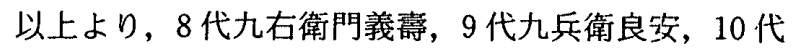
九兵衛義藝と, 幕末には 3 代にわたり大棟梁や大棟梁立， 大工棟梁を彫物大工棟梁と兼任する者が出た。

\section{3. 高松家について}

\section{(1) 出身地}

高松家の由緒に関する史料には, 菩提寺の祥禅寺の過 去帳・墓碑及び蝎川親治氏所蔵の『蜷川家大概格写』(以 下『概略』と記す）がある。『概略】は, 表紙外題に「蟟 川家大概略写 祥禅寺」, 奥書に「文政十一戌子年十一 月上野国勢多郡花輪 赤城山祥禅寺 (印)」とあり, これらを併せて考えると, 原本を祥禅寺が文政 11 年 （1828）に書き写したものと考えられる。内容は，蟟川 家からの奉納物・奇付金の書き上げ及び蟬川家（および 高松家) の系譜で, 系譜の最後に「以上 右は宝暦十三 未年」とある所から，系譜が宝暦 13 年 (1763) に記さ れたことがわかる。

『概略』によれば，当家はもともと蟟川家の出で，蟟 川家は蟟川将監の代に上野国に移り住み, 続く又左衛門 （寛文 20 年没 $1643 ） \cdot$ 佐石衛門（貞享 2 年没 1685） は共に沼田城主真田家に仕え，佐右衛門は上州花輪村に 住んでいた。高松家初代の又八郎は佐右衛門の子で，寛 文頃に江戸へ出て㓮物大工となり，そのときに高松又八 郎と改名した

他の史料をみると，墓碑銘は，初代を又八と記し，江 户神田九軒町に住んでいた ${ }^{26)}$ が，この墓のある菩提寺の 祥禅寺が花輪村にあることや, 蟟川佐右衛門と高松家の 墓があることから，遅くとも䗷川佐右衛門以後には『概 略』が記すように上州花輪村が先祖以来の縁深い土地に なったことは誤りない。一方, 関東の彫物大工の系図で

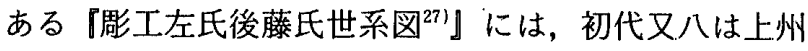
沼田の生まれとあり ${ }^{281}$ ，いずれにしても高松家の初代の 出身地は上野国であったと考えられる。 


\section{（2）歴代当主と活動}

史料の内，最も信頼できる過去帳によれば，高松家の 初代は又八 (享保元年 2 月·5 日没 .1716)，2 代は初代 の次男の又六 (明和 6 年 6 月 10 日没 1769) である ${ }^{29) 。 ~}$

また; 『概略』は初代から 3 代までを記し，いずれも 又八郎を名乗ったとしているので， 2 代も又八（郎）を 名乗った可能性があり，3代まで継承されたと考えても よかろう。なお， 3 代又八郎の条には「右又八郎家督相 続」とあり，『概略」が記された宝暦 13 年 (1763) には 3 代又八郎が家督を継いでいたことになる30。

また，関東の䧓物大工の系図である『彫工左氏後藤氏 世系図」には, 又八邦教・又六頼直・又八頼品の 3 代が 記されている。各人の実名の内, 初代については戒名に も「邦教」が使われているので誤りはなく，2代・3代 についても仮名が一致し，根拠となる史料に基ついて記 したと判断されるので，実名についてはこの系図通りで あったと考えられる。

4 代以後については, 過去帳・『概略』あるいは『彫 工左氏後藤氏世系図』のいずれにもなく，『阙工左氏後 藤氏世系図」の 3 代又八頼品条に「諸国経歴」とある31 ので, 3 代又八 (郎) は幕府の作事からも離れ, その後 に諸国を遍歴したと考えられ，彫物大工としての家系も 3 代で絶えた可能性が強い。

すなわち, 当家は初代又八 (郎) 邦教 (享保元年没) 2 代又六 (又八 (郎) ) 頼直 (明和 6 .年没) 3 代又八郎 頼品と 3 代にわたり継承されたが，この 3 代で翢物大工 が絶えた可能性が強い。

次に当家の者が実際の作事に関与した例をみてゆく が，すでに『鈴木修理日記』(東京都立中央図畫館蔵東 京誌料）の記事によって，元禄 5 年に高松又八郎が婤物 大工棟梁の立場にあったと考えられることとは明らかにし

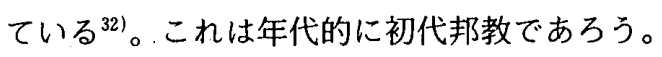

当家の者が造営記録にみられる初見は，宝永 4 年 （1707）の手力雄神社本殿（千葉県館山市）の「江戸 高松又八」33) である。また, 幕府の作事における初見は, 正徳 3 年 (1713) の芝文昭院霊廟造営の高松又八郎 ${ }^{34}$ で, 又八郎はこのときには䧓物大工棟梁として造営に参加し たことになる。年代的にこれらの又八郎は初代邦教と考 えられる。また, 享保 16 年 (1730) の日光大鿕院霊廟 の修理 ${ }^{35)}$ ・宝暦 4 年 (1754)，の日光東照宮修理 ${ }^{36)} \cdot$ 明和 3 年 $(1766)$ の芝台徳院霊廟修理 ${ }^{37}$ にも高松又六が関与 している。これらは仮名や年代からいずれも 2 代頼直に 当たると考えられる。このほか门㰹工左氏後藤氏世系図」 には, 初代邦教が厳有院・常憲院霊欫を, 2 代頼直が有 章院霊廟を，3代頼品が惊信院霊廟をそれぞれ担当した と記されるが，年代的にも矛盾しないのでこれらの彫 物38をそれぞれが担当した可能性が強い。

以上から, 高松家は初代が関東の上州花輪村の出身で
寛文頃に江戸へ出て彫物大工になり，その時期は，遅く とも元禄 5 年で, 正徳 3 年には幕府の造営に彫物大工棟 梁として参加したことが明らかである。しかし，3代ま でしか継承されず，管見では幕府の作事に関与したのは 正徳 3 年から明和 3 年までである。これは, 和泉家が, その先祖が泉州和泉郡和泉の出身で, 元禄 3 年以後幕末 まで幕府の彫物大工棟梁を継承しており，彫物大工をは じめた時期が江戸初期にまで遡る可能性があるのに対 し, 出身が関東であること, 活動期間が短いことにおい て対照的である。

\section{4. 彫物大工棟梁の所属}

次に; 彫物大工棟梁の所属について検討する。

日光東照宮延享度修理に参加した和泉家 7 代忠兵衛貞 福之高松家 2 代又六頼直は, 「延亭元甲子年. 日光御宮 御仮殿御旅所所々御修復御彫物工割帳 御作事方」 ${ }^{39}$ に 「御宮御仮殿御旅所 彫物大工書出シ 工数 七千三百 四拾八人半 彫物大工 高松又六 同 和泉忠兵衛」と あることから共に作事方に所属していたことがわかる。

肩書をみると, 天保度の日光東照宮修理に参加した和 泉家の 9 代九兵衛良安は, 「御作事方諸棟梁」の中の.「御 彫物師」40)で, 家屋敷譲渡の書類では「御作事方御大工 頭支配䧓物方」であっだ11。また，同家 10 代の九兵衛 義藝は, 元治度西丸造営(2)においては「御作事方」の「彫 物棟梁」で,さらに同家 11 代の嘉右衛門信義は明治 9 年の「増上寺御本堂御再建御普請之儀二付願書 ${ }^{43}$ 」によ ると「元御作事方彫物棟梁」であった。

また, 8 代義壽や 9 代良安 $\cdot 10$ 代義藝が作事方大棟梁 や大棟梁並・大棟梁見習に昇格していることも考え合わ せると, この 3 代は共に作事方に所属していたと考えら れる。

しかし, 由緒書によれば和泉家 8 代の九右衛門義壽は 天明 6 年 (1786) の浚明院霊廟の作事, および同年の厳 有院霊廟の作事に小普請方として参加していだ4)。由緒 書には他に小普請方として作事に関与した例はみられな いが, 由緒書が主に作事方に提出することを目的として 作成されたために小普請方での業績が記されないという ことも考えられ，他にも例があった可能性がある。また， 小普請方に所属した彫物大工棟梁の存在もこれまで確認 されていないので，彫物大工棟梁である和泉あるいは高 松家が小普請方の作事にも参加したことも考えられる。

すなわち, 䧓物大工棟梁は, 和泉家の 7 代貞福 $\cdot 8$ 代 義壽・9 代良安・10 代義藝および高松家 2 代又六が作事 方に所属したことが確認され，両家とも代々作事方に属 したと考えられる。また，作事方の仕事だけでなく小普 請方.作事にも関与していたこともあった。 


\section{5. 彫物大工棟梁の地位}

「万延度江戸城御本丸御普請記』によると，和泉家 10 代九兵衛義藝は万延度江戸城本丸造営において「彫物棟 梁」を勤めており，この時「䧓物棟梁」は他の大鋸・鍛 冶・錺・石等の各棟梁と並ぶ棟梁であった おける万延度の組織を示すとされる大島家所蔵の系統図 によると，諸棟梁は大棟梁の下に大工棟梁・諸請負人と 並んでいだ66。

したがって，作事において棟梁は大工棟梁とその他の 諸棟梁に区別されていて，彫物大工棟梁は諸棟梁の内に 含まれ大鋸・鍛冶・錺・石等の各棟梁と同格で, 大工棟 梁と並ぶ位置にあった。

また，幕末の和泉家には大棟梁や大工棟梁を兼任する ものがいた。

大工棟梁や大棟梁並・大棟梁などを兼任後の作事にお いて, 䧓物大工出身の和泉家の各代がどのような役割を 果たしていたのかは詳細に知ることはできないが, 由緒 書の 8 代義鲥条をみると, 大工棟梁兼任当時の記録とし て,

文化 12 年 (1815) 条

增上寺 玉樹院様御廟御用奉相勤候 大工方

文政 6 年 (1823) 8 月条

文政六癸未年八月 日光山 御普請先御見分御用奉相 勤候 大工方

とあって，「大工方」を明記する作事記録 ${ }^{47)}$ が，彫物を 担当した記録の他に加わっている。大工棟梁として䧓物 以外の作事に参加したことが窅える。

また, 大棟梁並兼任当時の天保 3 年 11 月 25 日条には, 増上寺 安国殿御宮御修復御用挂惣被仰付野扶持方七 人扶持被下置, 御彫物御 用共被仰付奉相勤候 とあり ${ }^{48)}$ ，この作事の担当は，作事全体と共に彫物にも 及ぶものであったことがわかる。

大棟梁並や大棟梁となった後は, この天保 3 年の記録 ほど明確ではないが，「普請」「「修復」「「模様替」など とだけ話され，「御彫物御用」などと特記されない作事 記録が続いており，8 代義壽は大棟梁として設計・管理 に携わっていたと推定できる。

一方, 高松家は, 初代又八邦教以前には大工等の工匠 とは縁のない家柄で，䧓物以外の工事に携わったりする こともなかったと考えられる。

\section{6. 結 語}

彫物大工棟梁の 2 家の内, 和泉家の先祖は和泉国和泉 の出で, 貞享 4 年頃から彫物大工として活羅しているこ とが確認でき, 幕府の工事では元禄 3 年の日光東照宮修 理にすでに関与していた。さらに彫物大工としての活動 は江戸初期まで遡る可能性が強い。そして代々この職を 継承し幕末まで続いている。
一方, 高松家は初代が上野国の花輪村の出身で, 彫物 大工として活躍するのは早くても寛文頃遅ければ元禄 5 年頃からと考えられ，彫物大工としての系譜は江戸初期 にまで遡らない。また, 初代の後に彫物大工を継承した のは 3 代までであって, 明和 3 年の芝台徳院霊廟修理後 まもなく幕府の工事からも離れたと考えられる。これら の彫物大工棟梁は平常, 作事方に所属していた。その地 位はほぼ作事方大工棟梁と同格で，幕末の和泉家からは 九右衛門義裖・九兵衛良安・九兵衛義藝の 3 代にわたり 作事方大棟梁や大棟梁並・大工棟梁を兼任する者が出 た。大棟梁として設計・監理の代事を勤めたと推定でき る。

なお，䧓物大工棟梁の 2 家と関東各地の彫物大工との 関連について次稿で述べたい。

注

1）拙稿「江戸幕府の作事において䧓物を担当した工匠の変 遷亡彫物大工棟梁の確立」(日本建築学会計画添論文報告 集 411 号, 1990 年 5 月)

2）「江戸幕府郮物大工楝梁和泉家の由緒書について一史料と しての信頼性の検討一」日本建築学会計画系論文報告集, 408 号, pp. 111 112, 1990 年 2 月

3）大熊喜邦「豊公聚楽第の大広間」(「建築史」 2 ), 昭和 15 年 1 月)

同家（和泉）の由緒書に依れば祖先は泉州和泉郡和泉 住岸上五郎右衛門源義忠で永正大永の比足利氏に壮へ たる人である。

4）出身地については, 由緒書 $F \cdot H \cdot K \cdot L \cdot M$ 加記してお $\eta$, 義信の菩提寺についてはこの内の $\mathrm{F} \cdot \mathrm{H} \cdot \mathrm{K} \cdot \mathrm{L} \cdot \mathrm{M}$ が記している。

例えば由緒書Fでは,

本国泉州和泉郡和泉住

足利義稙公仕，大永年中

岸上五良右衛門源義忠 (中略)

義忠次男泉州和泉郡和泉産

番匠彫工祖

岸上甚五郎左義信

(中略)

信政長男小三郎改慶長四年より

江戸住居

七代目

岸上小右衛門義繁

(下略)

とあり,

また，Hには、

泉州和泉郡和泉国住

岸上五郎右衛門源義忠

代々足利家仕, 永正大永頃

義忠末子五男

岸上甚五郎義信

永正元年甲子年三月五日誕生，永禄十二巳已年六十六 歳卒寺八泉州和泉郡貝塚村願泉寺, 十歳之節より日々 山林二入, 職分修行いたし夜々䧓物等迄修行いたし十 
六歳之節大和国多武峯十三重荅建之，泉州堺妙国寺門 建之，蟇股猿厝物彫刻之，伏見岩清水八幡宮拝殿建之， 䧓物共彫刻之, 火防之法致候哉, 今二連綿二御座候 とある。

5）「重要文化財 岩木山神社本殿外四棟修理工事報告書」昭 和 53 年

6）「了観師記 万記録」(「日本都市生活史料集成九 門前町 篇」学習研究社 1977 年所収)

一、同 (御堂) 再興寞文三年癸卯年 寺内門徒近在 門徒助成 八十八年二成 (中略)

一、彫物 和泉守豊後守但馬守兄弟

一、御堂御择ノ上天人ノ彩色䧓物八古堂ノ時より作 者不知 菊籠㰹八和泉守，外ノ彫物ハ先和泉ノ差図ニテ 其

時分ノ上手共二彫七候, 和泉細工ト云テモ不苦 御堂再興ノ棟梁八和泉守ナリ, 別帳二委記アリ, 和泉八貝塚ノ産, 後江府へ参, 再興ノ節呼二遗 来

(下略）

7）願泉寺蔵持仏堂棟札に,

(表)「持仏堂䧓物

北松藤 和泉守貞由作

中華瑟 ， 豊後守定勝作

南松椿 但馬守定吉作」

（裹）「右三作當国南郡三松村之産岸上万兵衛長男但馬 守定吉次男和泉守貞由三男豊後守定勝三子貝塚 住居

$$
\begin{gathered}
\text { 文化十四丁丑歳持仏堂再造之時記之 } \\
\text { 卜半十世了真花押」 }
\end{gathered}
$$
とある。文化 14 年 (1817) の持仏堂再建に当り，以前の 彫物を再利用する際に記されたと考えられる。

8）由緒書 F。9 代義一次男但馬条に「岸上但馬 幼年之節 泉州岸上甚十郎跡目養子に罷成候」とあり，泉州に岸上 家が存続していたことを示している。

9）「天保十一庚子年八月 表紙附る十八冊之内」と端裏書に あるので天保 11 年以前に記されたものである。最初に「貝 塚䧓物并大工由緒書」が記され，続いて「貝塚彫物師」 と題された系図がある。「貝塚幈物并大工由緒毒」の最後 に，「宝暦十一巳年極月日 泉州貝塚䧓物大工 岸上武左 衛門周房」とあって, 宝暦 11 年 (1761) に泉州貝塚の彫 物大工の岸上武左衛門周房が曲緒を記していることがわ かる。系図の書体は前の由緒書と同一と判断できるので, この系図も由緒書と共に宝暦 11 年に岸上武左衛門によっ て記されたと考えられる。

10）岸上万兵衛次男の和泉守貞由の孫に「加右衛門近直初名 太郎兵衛 実富久仁助男」とある。また, 佐野五兵衛の 条に「和泉加右衛門近直女兄弟之子」とあって, 加右衛 門近直は和泉姓を名乗っていたことがわかる。和泉守貞 由は同書の他の箇所で「今之御堂願泉寺者寛文三年岸上 和泉守棟梁時八十一歳後於江戸死去」と記されていて， 岸上姓を名乗り，寛文三年に 81 才の高齢であったことが わかるので，孫の加右衛門の活動年代は 17 世紀後期と考 えられる。

11) 向拝手挟上端墨書 ([重要文化財 新長谷寺本堂修理工事
報告畫」昭和 28 年)

貞享四丁卯三月廿六日

奉行金剛院亮範十六世

泉州堺大島郡大工町三丁目瀻物師岸上市郎兵衛真勝

12）【輪番所日記】(【難波別院史】難波別院史編籍委員会編 昭和 53 年)

(前略)

○彫物市 大坂 岸上五兵衛尉 京 清 水安之丞尉 京 長谷川與右

衛門尉 京 丸山新之丞

とある。この内，丸山新之丞は，谷直樹「中井家六箇国 大工支配の成立と展開に関する研究」(私家版 昭和 58 年 9 月）が元禄 5 年 (1692) 当時中井家配下の棟梁で, 延宝 4 年 (1646) に哲願寺庤子の郮物を, 宝暦 6 年 (1756) には西本願寺本堂御拝の象鼻を請負い，代々彫物大工と して活躍したことが知られるとする丸山新之丞に当たる と考えられるので，大坂の岸上五郎兵衛尉も郕物を担当 した彫物大工と考えられる。「貝塚大工之由緒，大覚寺宮 令旨, 棟梁系図」(願泉寺蔵)にみえる, 和泉守貞由姪 (マ マ) 五左衛門の子の「駿河 五兵衛，大坂住，享保五年 大坂西御堂門出来之時受領」は，この五兵衛に当たると 考えられる。

13）由緒書 $H \cdot K \cdot L \cdot M$, 注 4）参照

14）前揭「江戸幕府䧓物大工棟梁和泉家の由緒書について一 史料としての信頼性の検討一」

15）例えば和泉 $Q$ ，義壽条

同（文化）四卯年七月五日大工棟梁職被仰付彫物方兼 相勤候様, 御作事奉行岩瀬加賀守申渡候旨, 御大工頭 和田源助申渡

16）例えば由緒書 $Q$, 義芼条

同（天保二）年十二月廿六日出精相勤候二付大棟梁並 被仰付御扶持方三人扶持被下置彫物方是迄之通相勤候 様，水野出羽守殿御書付を以被仰渡候段於中之御廊下 御作事奉行須田大隅守申渡

17）例えば由緒書 $Q$ ，義䬼条

同（天保）五午年八月十日年来出精相勤候二付大棟梁 被仰付御扶持方七人扶持増被下置，都合拾人扶持成下 候旨，大久保加賀守殿御書付を以被仰渡候段御作事奉 行神尾備中守川井長門守申渡且彫物職之儀も是迄之通 相心得候样被仰渡

18）例えば由緒書 $Q$ ，良安条

天保五午年十一月二日大棟梁見習相勤候梯松平周防守 殿御書付 $\ni$ 以被仰渡候段御作事奉行神尾備中守殿申渡

19）例えば由緒書 $Q$ ，良安条

同（天保十二）年十一月五日大棟梁見習差免，前々之 通御彫物御用可相勤候旨, 水野越前守殿御差図 $\exists$ 以被 仰渡

20）例えば由緒書 $Q$ ，良安条

同（天保）十四卯年正月廿日 右御用真実格別出精致 冥加之御奉公相勤二付, 御作事奉行石河土佐守殿御誉 之御褒詞下置，水野越前守殿御差図請御大工頭支配大 工棟梁並被仰付

21）例えば由緒書 $Q$ ，義藝条

御本丸御普請初度御用中天保十五辰年十月十八日御彫 物見習被仰付

22）例えば由緒書 $Q$ ，義藝条 
同 (嘉永五) 年十二月朔日父仰職彫物方被仰付

23）例えば由緒書 $Q$ ，義藝条

同（万延元）年十一月五日 御本丸御普請御用精入骨 折相勤候二付, 大棟梁並被仰付御扶持方七人扶持下置 候旨, 久世大和守殿御書付 7 以被仰渡候段，御作事奉 行松本駿河守殿申渡

24）前揭「江戸幕府彫物大工棟梁和泉家の由緒書について一 史料としての信頼性の検討一」

25）「概略」によれば, 将監の条に, 昔時大徳寺之宮附二而, 上野国佐渡之渡り江引移儿 とあり, 又左衛門の条に

蜷川又左衛門 寛永廿癸未十二月廿八日當寺江葬儿 法名円修院山叟陽雲居士

右上州沼田城主真田阿波守殿二仕七知行二干石

佐右衛門の条に

蜷川佐右衛門 貞享二乙丑三月廿三日卒 當寺江葬儿 法名了性院鎖雲雍関居士

右同真田阿波主殿二仕七知行七百石干後上州花輸村 二住居又

佐平太の条に，

䗳川佐平太 享保元丙甲閏三月五日卒, 當寺江茂廟所 有之

法名伝心院外空邦教居士

右寛文年中江府江罷越彫物職を請, 高松又八郎之 改名, 公儀御用達之成, 浅草今戸慶養寺江葬儿 とある。

26) 祥禅寺墓碑に

江戸神田九軒丁居住御彫物屋棟梁俗名高松亦八當亦八 $\square \square$ ए

とある。

27）東京国立博物館蔵

緒言に,

一, 世系者先人之記所, 従左氏元禄以前之人, 而其後 不記，亦先師末番者間有，尚本国住所迄悉改正， 而後人伝, 雖然筆走順逆可有, 猶誤多事後哲訂正俟, 而已

于時文化七龍集庚午仲夏吉辰 東都彫工匠

後藤惣八正常

行年七十六

とあって，元禄以前の彫物大工について記した系図を基 に文化 7 年 (1810) に江戸の彫物大工後藤愫八正常が著 わした系図であることがわかるが，実際には明治期に活 躍した壠物大工名まで記されており，その後明治期にも 補筆があったと考えられる。ただし，同史料は同一人の 手によって一度に記されたもので，原本の写しであると 考えられる。

28）初代邦教条に,

邦教 俊元門人高松又八上州沼田産

江戸九軒町住

$$
\text { 巌廟 御用勤 }
$$

とある。

29）過去帳には,

䗷川氏霊位 先檀當寺檀那又八代 $\exists$ リ江戸神田九軒丁 居住。御本丸倜物棟梁相勤 又八方 (より) 高松氏改 (中略)
一、伝心院 外空邦教居士 享保元丙申二月五日俗名 高松又八事佐右衛門子, 御本丸彫物棟梁

一、円照院 大安智鏡大姉 宝永甲申五月二十三日高 松又八妻

(中略)

一、祖山教意居士

明和六丑年六月十日高松 又六事先又八二男

（下略）

とある。

30）【概略」については, 初代は注 25）の通りで，2代につい ては,

本名蟟川氏

高松又八郎 先又八郎次男藤五郎舎弟也

正徳三巳年より御彫物御用相勤，今以相勤候

3 代については

二代目又八良嫡子

高松又八郎

右又八郎家督相続

とある。

31）「彫工左氏後藤氏世系図」には, 初代邦教の条（注 28） に続いて

2 代頼直の条に

頼直 邦教男 二代高松又六 神田九軒町住後二下谷金杉町死 章廟之御用勤

3 代頼品の条に,

頼品 頼直男 三代目高松又八 諸国経歴 惊心院様御廟御用勤 とある。

32）前揭「江戸幕府の作事において彫物を担当した工匠の変 遷と䧓物大工棟梁の確立」

33）修理銘札

34）「正徳三年癸巳三月より五月迄 増上寺御普請公儀請負町 人切手留帳」(岡山大学附属図费館蔵) に

二、同 (銀) 五拾貫目 䧓物大工作料 内訳 高松又八郎, 中村新三 郎, 今泉彦八郎切柇

一、米百石 彫物大工飯米

右三人之切手

35）『享保十六年 日光御霊屋御修復御入用御勘定帳御勘定 所」内藤家文書 (明治大学刑事博物館蔵) に,

一、銀壱貫八百六拾四多五分 彫物大工作料

彫物大工

高松又八

とある。

36）【在国 日光御宮御修復御用留控」蜂須賀家文軎（国立史 料館蔵)。寛延あるいは宝暦といった年紀や，大棟梁辻内 豊後・大谷甲斐の名がみえることから一見して宝暦度修 理の記録とわかり，この内に

軫物大工 高松又八 同 和泉忠兵衛 とある。

また、この他に『御宮御上棟之節諸棟梁并行列書】蜂 須賀家文書（国立史料館蔵）に， 素袍 棟梁 高松又八 
とある。

37）「安永七戌年十一月 紅葉山御霊屋御修復記 四」(増上 寺蔵) 中に, 紅葉山霊廟の修復棟札の参考として明和 3 年 (1766) の台徳院霊廟修理の棟札写しがあり,ここに 䧓物大工 高松又六 和泉忠兵衛 とある。

38）棟札等によれば, 厳有院霊廟は天和元年 (1681) 造営, 元禄 11 年 (1689) 焼失, 同 12 年再造営。常憲院霊廟は 宝永 6 年 (1709) 造営。有章院霊廟は豙保 2 年 (1717) 造営である。

39）松平文庫（福井県立図書館蔵）

40）「御宮御修復挂り御役人附文政十四年上り天保三年迄 全」(杤木県立図書館蔵)

41)「一, 家屋敷譲請度御添翰智」(「撰要永久録】, 「東京市史 稿」市街編 43 昭和 31 年所収）に「嘉永四亥年正月廿 三日」の年紀と共に「御作事方御大工頭支配㰹物方和泉 九兵衛」とあり，年代的にこの九兵衛は 9 代の良安と考 えられる。

42）「江戸城仮御殿御表向御中奥向大奥向総地絵図」(東京都 立中央図書館蔵)

奥書に「元治元甲子年十二月 大棟梁 甲良筑前控 (印)」の年紀亡署名をもつこの絵図に記された「御普請 御用掛名面」の「御作事方表掛」の中に「彫物棟梁 和 泉但馬」とある。

43）和泉家蔵。表紙に「元御作事方彫物棟梁」とある。

44）和泉家由緒書 $Q ， 8$ 代九右衛門義壽条

天明六丙午上野 浚明院御廟御霊屋御彫物奉相勤并上 野紅葉山共, 大辞院浚明院御宮殿御須雨檀并仮御宮殿 御須䨋檩并御用向於小普請方奉相勤候。
45）「万延度江戸城御本丸御普請記」(「東京市史稿」皇城編三 大正元年所収)

「御普請御用掛名面」の「諸棟梁」条に,

$\begin{array}{llll}\text { 大鋸棟梁 } & \text { 桜井肥後 } & \text { 鍛冶棟梁 } & \text { 高井伊豫 } \\ \text { 錺棟梁 } & \text { 松井近江 } & \text { 石方棟梁 } & \text { 刍岡石見 } \\ \text { 石方 } & \text { 石津伝十郎 } & \text { 䧓物棟梁 } & \text { 和泉但馬 } \\ & \text { (下略) } & & \end{array}$

とある。

46）田辺泰「江戸幕府作事方職制に就いて」建築学会大会論 文集 昭和 10 年 4 月

系統図は，その末に「右万延度御普請之節手続」とあり， 甲良家 12 代大島盈株氏が筆録されたもので，おそらく 大島氏が作成されたものとされている。系統図は次の とおりである。

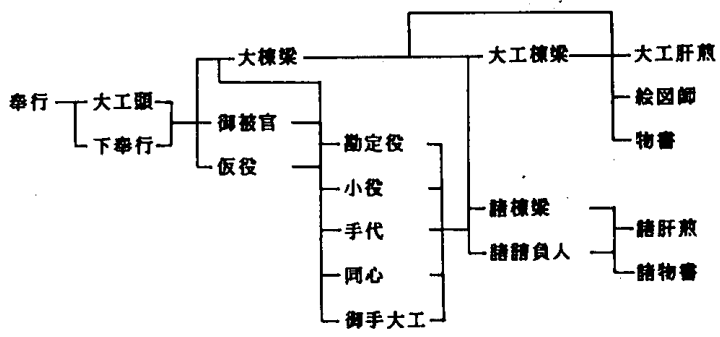

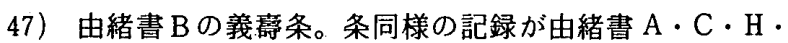
$\mathrm{K} \cdot \mathrm{L} ・ \mathrm{M}$ にある。

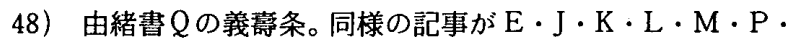
$\mathrm{R} \cdot Q$ にある。

(1990 年 1 月 10 日原稿受理, 1990 年 5 月 28 日採用決定） 